\title{
The (Un)Making of a Worker Poet: The Case of Md Mukul Hossine and Migrant Worker Writings in Singapore ${ }^{1}$
}

\author{
Luka Lei Zhang, Nanyang Technological University, Singapore
}

\begin{abstract}
This article discusses the migrant worker poet Md Mukul Hossine. Showing Mukul as the representative migrant worker poet also severely restricted and complicated his process of 'becoming' a poet. From a Marxist standpoint, the Singaporean literati's dismissal of Mukul reveals the predicament of being a working-class writer in today's neoliberal market. The particular bourgeoise 'production mode' of working-class literature in Singapore first 'made', then 'consumed' and ultimately 'condemned' Mukul. First, I examine the publication process of Mukul's poetry and its success followed by a series of problems. In the second section, I offer a close reading of Mukul's poems understanding Mukul's poetics and struggles as a migrant worker poet as his poetry is seldom examined in literary criticism. Finally, I argue that the representation of migrant workers writers such as Mukul is problematic due to the nature of the whole system: how they are empowered in such a context equally does harm to them. This mode again reproduces the systematic structure of power hegemony and social inequality through the field of literature.
\end{abstract}

\section{Keywords}

Working-class poetry, migration, neoliberalism, Singapore

\section{Introducing Md Mukul Houssine and his success in Singapore}

When discussing migrant worker writings in contemporary Singapore, it is impossible to neglect Md Mukul Hossine's works and his experiences as a poet. Md Mukul Hossine was born in Bangladesh in 1989 and arrived in Singapore in 2008. He worked in the construction sector. His first poetry collection, Me Migrant, published in 2016 by Singaporean publishing house Ethos Books, gained massive media coverage and a relatively wide readership since its publication. Mukul thus won a reputation as the representative of migrant worker poets in Singapore. In the following year, Mukul published his second poetry collection Braving Life with HealthServe, a non-profit organization supporting migrant workers in Singapore. He also published a self-sponsored poetry collection Unfulfilled Desire in Bengali.

The production of Me Migrant was a complicated process. It was originally written by $\mathrm{Md}$ Mukul Hossine in Bengali, then translated into English by Fariha Imran and Farouk Ahammed, and finally 'transcreated' by the established Singaporean writer Cyril Wong. There is no detailed information on the first translators in the book. However, an editorial note in the book,

\footnotetext{
${ }^{1}$ I sincerely thank two anonymous reviewers for their helpful comments and suggestions.
} 
introduces Cyril Wong as 'a Singapore Literature Prize-winning poet...a finalist for the Singapore Book Awards... a past recipient of the National Arts Council's Young Artist Award for Literature' (Hossine 2016 p.7) Wong offers a brief explanation of the methodology he employed, stating that

I have done my best to mirror the intriguing combination of Mukul's unpretentious voice and his artistic aspirations through my transcreation. My frequent meetings and conversations with Mukul were essential in helping me decide not only how the translated poems might read or sound, but also how they should flow into each other.

As literary critic Richard Angus Whitehead indicated: ' 'Transcreation' is a word unlisted in the Oxford English Dictionary, but from Wong's 'Editorial Note' to 'Me Migrant' the word in this context seems to cover not only translating but also 'rewriting and editing', (Whitehead 2017). Thanks to Wong's efforts, Mukul's poetry was able to reach more readers in Singapore and the English-speaking world. Next to a wider readership, the book also greatly appealed to the media and was promoted in social events, such as poetry readings and talks for different audiences, including academics just as myself who are incapable of reading his works in their original language.

Mukul's second book, Braving Life contains 24 poems in English, first translated from Bengali by Swagata Sen Pillai and then again 'transcreated' by Cyril Wong. Interestingly, the book also includes Chinese translations of all poems face to face to the English versions. On the acknowledgments page of the book, titled 'gratitude', the founder of HealthServe Goh Wei Leong declares that 'we are equally grateful to the students of Nanyang Girls' High School, who readily took on the challenge of translating Mukul's poems from English to Mandarin Chinese' (Hossine 2017).

Before delving into Mukul's poetry , I would like to discuss Mukul's story of being a poet in Singapore, focusing especially on his relations with the circle of people who helped to produce his works, and the dynamics between Mukul and Singaporean literati. In fact, the path of 'making' Mukul as a 'successful' migrant worker poet is rather bent, if not controversial.

Right after the publication of Me Migrant, Mukul was introduced and praised in various media including local newspapers and TV shows. He also attended many literary events with local politicians and writers. However, things changed very rapidly for the young poet. In the author's note of Braving Life, Mukul sorrowfully states that 'I have always tried to express my emotions in words - in poetry. I have faced a lot of criticism too because of this, but my writing gave me peace. In this foreign land I have lost my job, and I have been ridiculed and berated for my literary passion' (Hossine 2017 p.3). Furthermore, in the preface written by Cyril Wong, it is mentioned that, 'at the same time, the poet no longer has a work permit until he is able to land another place of employment' (Hossine 2017 p. 9).

During a conversation I had with a friend of Mukul in Singapore in January 2018, she told me the reason why Mukul lost his job and work permit. Mukul's ex-boss thought he had gotten too 'famous' to work for him. It concerned the boss that Mukul had made too many connections with people in literary circles and media industries. Obviously, the boss did not want to draw attention to his construction industry business and potentially expose it to public scrutiny about working or living conditions of migrant workers. Finding it very difficult to find any job as a 
migrant worker once he had become famous, Mukul had to go back to his home in Bangladesh in $2017^{2}$.

Similar to MD Sharif Uddin ${ }^{3}$ and many other migrant workers, it seems that being rapidly translated into English was Mukul's 'entrance ticket' for being read and recognized. Mukul's case begs the question, however, what price a migrant worker may have to pay for such recognition? What may happen to them and their writings once they have been given a public stage?

Unable to read Mukul's poetry in its original language, it is somewhat disquieting for me to attempt analyzing his poems after their 'transcreation' in English by Wong, especially after having witnessed Mukul's rather overwhelming reading in Bengali. I keep wondering, what is the gap between what I read in the printed book and what I heard from his voice? Is there something lost or is there something gained in this process of translation and transcreation? I am not, however, making the point here that poetry cannot be translated or studied in translation. Having gratitude towards the translators for their hard work, I yet suggest that in the case of migrant workers writing today in Singapore, the act of translating demands specific attention. While we discuss and study poetry collections such as Me Migrant, it is a necessity for us to bear in mind the 'production' process of the book, and the complicated power dynamics behind the translation, transcreation, and publication.

Classic translation issues have already been examined by other scholars who studied Mukul's poetry. For instance, Whitehead reminds us in a general manner that, 'we are still some way from if not wholly, then acceptably satisfactory translations of Bengali migrant poetry in Singapore. Simply, the majority of translators lack equal proficiency in both Bengali and English language and culture' (Whitehead 2017). In addition to this concern, he also reveals that the migrant worker poets themselves are not fully convinced by and satisfied with the English translation of their works.

To a significant extent, the 'transcreation' of Mukul's works by Cyril Wong reminds me of the collaboration between Tan Kok Seng ${ }^{4}$ and Austin Coates ${ }^{5}$. Both Md Mukul Hossine and Tan Kok Seng, as working-class writers who started writing in their native language, finally published literary works in English with the help of English-speaking professionals, or elites, in Singapore. Both Wong and Coates were impressed by the writings and enthralled by the working-class life experience of the authors they translated, although they were dealing with different literary forms, one with autobiography and the other with poetry.

After almost five decades, it seems that the narrative power of a colonial British writer who translated a Singaporean coolie has been passed on to an accomplished Singaporean poet rewriting a Bangladeshi migrant worker. From the perspective of the working-class, it may be asked if there is any shift of a power dynamic here at all? Has there been any change of the situation of 'subalterns who cannot speak' in their mother tongue? It may seem that along with

\footnotetext{
${ }^{2}$ In Singapore, the migrant workers can only stay with a valid work-permit issued by the government.

${ }^{3}$ Md Sharif Uddin is a migrant worker writer in Singapore. I have discussed his work in Zhang (2020).

${ }^{4}$ Tan Kok Seng (1939- ) is a working-class writer from Singapore. His works include Son of Singapore (1972), Man of Malaysia(1974), Eye on the World(1975), Three Sisters of Sz(1979), and the Chinese edition of Son of Singapore, Xinjiapo Zai 《新加坡仔》(1985). Tan's books are all published with the support of Austin Coates. ${ }^{5}$ Austin Coates (1922-1997) was a British colonial civil servant and author of many books including fictional works such as City of Broken Promises (1967) and The Road (1959) and historical books such as A Macao Narrative (1978) and Macao and the British, 1637-1842 (1988).
} 
the progress of the nation, the only thing that changed for the working-class writer is that instead of needing an English-language patron with a colonial background, they now need a Singaporean English-language writer with a post-colonial background. Can this be regarded as a real transfer of power?

In order to reflect on the production of working-class literature from Singapore, with both Tan and Mukul in mind, we can bring to the table what Bassnett and Trivedi described as the 'shameful history of the role of translation.' They observed that 'the close relationship between colonization and translation has come under scrutiny; we can now perceive the extent to which translation was for centuries a one-way process, with texts being translated into European languages for European consumption, rather than as part of a reciprocal process of exchange' (Bassnett \&Trivedi 1999 p.5). In the light of these remarks, we may ask at this point if the translation or transcreation of migrant worker poetry into English in Singapore today still parallels a colonial one-way process where the literature of the 'subaltern' is merely propped up and ornamented for bourgeoise consumption? The answer, I am afraid, may be a yes. And here I offer two major reasons for this affirmative anwer.

Firstly, on a rather large scale, migrant worker writings served the function of showcasing the life of migrant workers in Singapore for the Singaporeans. As discussed somewhere else ${ }^{6}$, there is a huge number of migrant workers in Singapore in various industries. Yet, ironically, at the same time they remain somehow 'invisible' for many locals. Given this situation there is an overriding idea that the migrant worker writings '...offer readers a glimpse into the thoughts, hopes, and dreams of Singapore's invisible workforce' (Lim 2017). More specifically, as the founder of HealthServe Goh Wei Leong remarked about Mukul's poetry, 'through his writing, Mukul has both inspired us and given us insight into the life of migrant workers in Singapore.' He adds: 'I am positive that this collection of poems will help us move towards this same end - that us in Singapore learn to appreciate our guest workers more' (Hossine 2017 p.71). In this way, under the umbrella of benevolent intentions and good wishes, it seems that the writings of the migrant workers are mainly endorsed for 'us' Singaporeans to learn about (and thereby distinguish ourselves from) the migrant 'them.' 'Their' writings are produced for 'our' curiosity, 'our' knowledge, and 'our' sympathy.

Tied to such 'showcasing' is a tendency of romanticizing the hard labor of the migrant workers by adoringly equating them to the founding generation of the Singaporeans. This fosters a nostalgic sentiment. When Md Mukul Hossine approached Ethos Books for publication opportunities, the company's founder Fong Hoe Fang was amazed by his writings. For Fong, Mukul's poetry is striking because, as he says, 'I am reminded of some Singapore pioneers who came from China and built a new Singapore, yet never lost their culture and love for the country of their birth and the memories there. ${ }^{7}$ Actually, Fong's opinion is not exceptional. In March 2019 when I attended the 'Migrant Heroes' Festival', a Singaporean official guest speaker for the event also remarked in his speech that the migrant workers reminded him of the Singaporean pioneers who industriously built the country with toiling labor. In line with such nostalgia, he declared: 'I salute you for your hard work for Singapore'. The speech echoed the

\footnotetext{
${ }^{6}$ See Zhang (2020).

${ }^{7}$ See: https://www.straitstimes.com/singapore/foreign-worker-who-published-book-started-by-scribblingpoetry-on-bags-of-cement

${ }^{8}$ It is organized by Sama Sama, an NGO seeking to 'redefine the narrative of migrant workers as unconventional leaders. In collaboration with NGO HealthServe, the campaign guides the public to see migrant workers in a different light and as more than their roles in Singapore'.
} 
sentiments Teo You Yenn reflects on in her book about the dominant narrative of the nation embraced by the Singaporean middle-class:

This is the story we tell ourselves about ourselves: Singapore became in a matter of a few decades a shining Global City. We were poor and now we are rich. We had no natural resources and now we can eat whatever we want, buy whatever we want, right in our own city. We were uneducated and now our children score among the highest in the world on standardized tests. We are safe, we are clean, we are amazing. We are amazing. We are amazing (Teo 2019 p.43).

This national narrative excludes the migrant workers from the 'contemporary us.' The logic rather is that 'we worked hard then and we salute you for working hard for us now.' Inhuman working conditions can be normalized and severe institutional policies restricting the rights of migrant workers become acceptable once platforms such as festivals for migrant workers are established to express the Singaporean gratitude. By defining 'the other', namely the migrant workers, the narrative at the same time still contributes to a Singaporean national identity of 'us'.

The second reason for my conclusion that certain colonial power structures are maintained in the production and reception of migrant worker literature in Singapore today was formed after watching a short documentary ${ }^{9}$ released by CNA Insider ${ }^{10}$ in 2019 and produced by Goh Chiew Tong and Ray Yeh. Titled 'He got too famous': A Construction Worker Turned Poet Pays the Price', the 13:24 minutes video documents Mukul's story after he went back to Bangladesh. It was partially filmed in his hometown Patgram and partially in Singapore. In the video, Mukul talks about his double life as a migrant worker and a fledgling poet in Singapore. He also talks about an exhibition of his paintings at his home in Bangladesh timed for the CNA filming (although his paintings are hardly shown in the video).

What astounded me most and what I intend to discuss here is how in the CNA video Cyril Wong, supported by Cai Yinzhou ${ }^{11}$ who also had helped to promote Mukul as a writer in the first place, bluntly comments about Mukul's supposed 'fault' as a migrant worker poet in Singapore who has too much 'ego'. I consider their comments critical since, on the one hand, they were the ones who had 'empowered' Mukul to grow into a celebrated migrant poet, while, on the other hand, their very way of producing Mukul as the representative migrant worker poet also severely restricted and complicated his process of 'becoming' a poet. More importantly, from a Marxist standpoint, their dismissal of Mukul reveals the predicament of being a working-class writer in today's neoliberal market. The particular bourgeoise 'production mode' of working-class literature in Singapore first 'made', then 'consumed' and ultimately 'condemned' Mukul.

A large part of the video consists of interviews with Cyril Wong and Cai Yinzhou (who is credited as Mukul's confidant in Singapore in the documentary). Having witnessed Mukul's

\footnotetext{
${ }^{9}$ See: https://www.channelnewsasia.com/news/cnainsider/migrant-poet-construction-worker-mukul-singaporebangladesh-11817978

${ }^{10}$ CNA is an English language news channel based in Singapore and founded in 1999.

${ }^{11}$ Cai Yinzhou is the founder of Geylang Adventures. He is actively engaged with migrant workers in Singapore. The website of Geylang Adventure states: 'We believe Geylang Adventures to be a platform for bottom-up initiative in changing social norms and perception. This is done through a series of pop-up social initiatives involving ordinary Singaporeans who choose to do a little extra'. See:

http://www.geylangadventures.com/about-us/
} 
successful and quick transformation after his first book's publication along with his constant struggles of going back to the construction industry, Wong reflects, 'I think the worst part about this experience was watching Mukul's ego basically explode with the fame. He thought as long as he was famous, every door would open for him, he wouldn't have to do construction anymore'( Goh \& Yeh 2019 05:21). Cai sees the same problematic aspect, stating that, 'He doesn't belong in construction. He is so articulate, he's so expressive. But that said, it is only on merit as a migrant worker that he is here. He should do that well before he even does anything else like poetry' (Goh \& Yeh 2019 06:31). It seems that for Wong and Cai, although Mukul published poetry, he should not have been eager to become famous as a poet but stick to his original status, that is, remain a migrant worker.

Wong's view echoes my point that the translation of migrant worker writings in Singapore largely serve as a postcolonial one-dimensional process for Singaporean bourgeoise consumption, since Mukul's identity is essentially petrified only as a migrant worker and not as someone who should claim poetic subjectivity. More interestingly, Wong's and Cai's statements also reveal that poetry (or literature in a broader sense) is regarded by them as something that does not truly befit a migrant worker and should not be prioritized in a worker's life. It seems that both Wong and Cai internalized and normalized to an extent the national policy and institutional regulations for migrant workers in Singapore. ${ }^{12}$

Reflecting on the fact that Mukul had to go back to Bangladesh when he was no longer able to find someone willing to employ him in Singapore, Cai states: 'The consequence of his action is that he has let his family suffer financially, compared to successful migrant workers who have come and gone, he has lost out'( Goh \& Yeh 2019 09:36). Here, Cai refers to the fact that Mukul's father borrowed around 20,000 Singapore dollars over the nine years to make it possible for Mukul to work in Singapore. Mukul, as almost all the migrant workers, had to pay most of this money to the agency through which he attained his job ${ }^{13}$. Cai's reflection shows a rather mainstream Singaporean misperception that migrant workers become 'successful' (in Cai's words) and rich by working in Singapore. In the article 'Myth and Facts: Migrant Workers in Singapore', Charan Bal recapitulates three main myths about migrant workers in Singapore, and among them, 'migrant workers will be rich when they return home' is the first. According to his research, 'In Singapore, it is, in fact, possible for migrant workers to become wealthy upon returning home. However, due to the nature of recruitment systems and government regulations, such outcomes are highly unlikely due to a number of reasons' (Bal 2017).

Whereas Cai's view is based on a misperception of the reality faced by migrant workers in Singapore, Wong directly accuses Mukul of being immature due to his wish to escape poverty while being a poet. In one part of the video, he says:

'Whether you come from a third world country or first world country, as long as you decide to be an artistic practitioner of any kind, you're not going to be a millionaire.

\footnotetext{
12 'They are deprived of the opportunity to settle down in the country and are not allowed to bring family members with them here. They are not allowed to change jobs and must leave the country when their contracts end or are terminated.' See: https://newnaratif.com/research/myths-and-facts-migrant-workers-in-singapore/ 13 'Bangladeshi construction workers pay an average of $\$ \$ 8,000-10,000$ (at the time, US\$6,126-7,657) - the equivalent of at least ten months of their potential wages in Singapore - to secure a job in Singapore. Part of the payment goes to employment agents and sub-agents in Bangladesh while the remainder is shared between the employer - in the form of kickbacks - and employment agents and their runners in Singapore (HOME and TWC2 2010, 10). Foreign workers and their families thus incur huge debts to secure jobs in Singapore and other labour-receiving countries. Workers unable to repay their loans face severe consequence' (Ong 2014 p.446).
} 
But with Mukul, he has this strange childlike innocence that as long as he was a famous poet, he will be rich, he will be able to take care of his parents, he will be able to build his home in Bangladesh, as long as he became famous' (Goh \& Yeh 2019 09:50, my emphasis).

Wong's description of Mukul as 'childlike' sounds rather condescending. His judgement is especially confounding when taking into account that he 'transcreated' Mukul's poem 'The Labourer's Lament.' In this poem, included in Braving Life, Mukul writes:

I have wept in helpless hunger

No one stopped to see

Bitter tears have swept my cheeks

Because I didn't have ten cents on me

The streets of Kakibuki know how pain fills my days

How crushed, I know, under my father's debt

I cannot repay

Another time, another life, had me weep for grain

I step out in the world today with love to gain

I have no love for money, my friend, don't want a mansion grand

I forget my pain to weep for men and roam in foreign land

Even if he worked through Mukul's poems in a literary sense, it seems difficult for Wong to grasp the existential state of a migrant worker like Mukul whose life is constituted by 'hunger' and 'debt' while working in a 'foreign land'. Mukul's more than understandable wish to advance his exploited life to a better condition, if only by means of being a recognized poet, is regarded as both too innocent and egotistic by Wong. In this poem, lines such as: 'I have no love for money, my friend, don't want a mansion grand' directly challenge Wong's assumption that Mukul is longing to become a 'millionaire' through artistic practice.

Even more worryingly, Wong further suggests: 'I would want Mukul to think less in terms of his ego, and more in terms of how he can give back to the community, and how he can grow as a poet, and as a human being, because those two things are not separate' (Goh \& Yeh 2019 12:04). Such a moralist demand from a bourgeoise, well-established perspective not only dismisses Mukul's artistic contributions as a working-class poet, but also reveals a hypocritical aspect of the literature field Wong is embedded in. If we follow Marx's idiom famously included in A Contribution to the Critique of Political Economy, 'It is not the consciousness of men that determines their existence, but their social existence that determines their consciousness' (Marx 2010 p.92) ${ }^{14}$, we gain an understanding that, as a matter of fact, Mukul's life conditions as a migrant worker are not determined by how he may 'grow as a 'poet' or in terms of how he may 'grow as a human' as Wong advises him to. In reality, such 'growth' is for him limited by the material life conditions he must endure. I quote Marx's explanation on

\footnotetext{
${ }^{14}$ As Marx explained, 'In the social production of their existence, men inevitably enter into definite relations, which are independent of their will, namely relations of production appropriate to a given stage in the development of their material forces of production. The totality of these relations of production constitutes the economic structure of society, the real foundation, on which arises a legal and political superstructure and to which correspond definite forms of social consciousness. The mode of production of material life conditions the general process of social, political and intellectual life. It is not the consciousness of men that determines their existence, but their social existence that determines their consciousness' (Marx 2010 p.92).
} 
social relation here to contest Wong's view (which I believe is not uncommon among Singapore literati) of Mukul as an overly ambitious poet to full of himself and offer a different perspective for understanding Mukul's condition and that of migrant worker writers in general.

Wong's accusation of Mukul as having a 'strange childlike innocence' deserves some further discussion, since, even if unintended, it reflects a certain prejudice informing Wong's views and also points to some literary aspects of Mukul's and other migrant workers' texts. It is interesting to note that in migrant worker writings, there is indeed a certain tendency of not fully embracing the Western 'enlightenment' ideal of the 'adult,' and a kind of urge of wanting to be a child, or, to be childish. Noticeably, Mukul, and other migrant worker writers often link the childhood and being a child to dear homeland, happy memories, and a sense of selfactualization. In a way, the harsh adult life as a migrant worker reinforces their imagination of an alternative life. For instance, in one of Omar Faruque Shipon ${ }^{15}$ 's mini stories published in Migrant Life: Stories of Reverist, the protagonist declares:

'I went to the cash counter for paying and bought two cones of ice-cream for us. My intention was to lick ice-cream and to talk with him. I sometimes eat ice cream like a child. I eat chocolate too in that manner. Whatever my age is, I never lost the kid in me. I believe everyone has a kid inside their heart which they enjoy sometimes. Sometimes they enjoy the show of being a kid. That's why, many of us behave childishly some time. We are normal human beings, because we have this kid in us' (Shipon 2019 p. 75).

Here, Shipon shows his embrace of childishness in one's life. Being a child in migrant worker writings is often related to a state of being carefree and happy. It is a way for them to escape the exploitation of capitalism and the despair of their lived reality.

Both in Mukul and Sharif's writings, traces of a 'child' can often be noticed. When Mukul dedicates a selection of his poems to his mother and family he situates himself as a beloved child. While he experiences loneliness and pain as a migrant worker in Singapore, he imagines himself as a 'child' longing for kindness and affection. For Sharif, the state of childhood represents a different world apart from the one where he has to toil and suffer. In his poem 'The Call' (Sharif 2017 p.121), he starts the poem with a short stanza:

Be with me on my childhood river

just you and me

and our sailboat too!

The 'childhood river' brings him to an existential mode of being 'pure' and 'true', and it represents a way to freedom when he suggests, 'let's lose our way. Will you?' However, Sharif converses the tone of the poem rapidly, presenting an opposite picture:
...Maybe love has
been distinguished,
maybe dreams are
dead. Survival, greed,
money; greed again.

\footnotetext{
${ }^{15}$ Omar Faruque Shipon is a migrant worker writer from Bangladesh currently working in a shipyard in Singapore as senior safety coordinator.
} 
These are the only things that interest you now.

Here, it seems that Sharif's 'childhood river' is replaced by a different reality 'now', where only 'greed' is stressed. The inclination towards 'having a child in us' and returning to the childhood in migrant worker writings speak to what Pheng Cheah encapsulated in these words: 'Global capitalism, however, incorporates peoples and populations into the world-system by tethering them to Western modernity's unrelenting march of progress and capitalist time and violently destroying other worlds and their temporalities' (Cheah 2016 p.19). The migrant worker writers I have discussed above offer us an alternative 'world' through the lens of a 'child' which differs from 'Western modernity's unrelenting march of progress and capitalist time'. While Western modernity champions progress and agency, the migrant worker writers long to return to a position where a glimpse of humanity and love can be located.

Coming back to Wong's comments at this point, it becomes clear that neither Wong nor Cai have any radical disagreement with or critical reflection toward the fact that migrant worker poets are badly exploited both economically and institutionally. Instead, they make the neoliberalist suggestion that Mukul ought to 'grow as a poet and as a human being' so that he will be able to 'give back to the community'. Further below in the next session when offering a critique of this 'mode' in which Mukul was 'made', I will revisit this neoliberal context which 'showcases' migrant worker writers. But before doing this, I wish to proceed with discussing Mukul's poetry in more detail.

\section{Getting to know Mukul's Poetry: Me Migrant and Braving Life}

Mukul mines the agony and loneliness of the life of a migrant worker with poems that shimmer with love, family, and religion. Most of the poems in his first poetry collection Me Migrant speak in a rather sad and lost tone, exploring his solitude and rootlessness as a migrant worker in Singapore. He also writes extensively on homesickness and his longing for empathy and kindness. One of the most poignant poems in this collection also titled 'Me Migrant' strikingly portraits the life of a migrant worker:

Me Migrant

Live overseas

Thousand thousand miles away

Me Migrant

Beyond borders

Mislaying smiles

Dawn to dusk the dawn again

Bearing sighs and a cry

inner heart

Love, compassion, kindness

Lose their meaning

Be careful: no one here

And nobody

To see and know such pain

Me Migrant

Live outdoors 


\section{Outside from you}

Reading the poem, one can easily sense a migrant worker's suffering from Mukul's plain and direct language, describing on the one hand the reality of the harsh working conditions, and on the other hand the loss and despair of his inner world. The poem ends with a symbolic line, emphasizing the marginalized and forgotten position of the migrant workers in the Singaporean society by using the words 'outdoors' and 'outside'. The poem is short and yet it registers different layers of voices. Starting by speaking from a 'me' perspective, it describes the experience of a migrant worker eager to show his migrant life. The eagerness transits to a compelling and solemn tone and then returns to the 'I', warning that 'Be careful: no one here / And nobody / To see and know such pain'. Readers immediately encounter a sense of frustration and loss. Yet the poet proceeds further to accompany the frustration with a note of accusation, when the voice speaks to 'you', claiming that 'me migrant / Live outdoors / Outside from you'. This claim marks the highlight of the poem, showing, as aforementioned, the migrant workers' marginalized position and exclusion from taking part in the Singaporean society.

In Mukul's poem 'Mother', following 'Me Migrant', the tone of impediment and frustration is even intensified:

Worn and decayed life

Surrounded by the thorny wire

I stand still like a beggar

A shadow of sorrow

in every pulsation

A long time I fail to see

My mother's tenderly smiling face

This stanza typifies Mukul's poetry to a great extent. Two central emotions recur in this poem, that is, pain caused by the 'worn and decayed' reality and emotional longing for tenderness and motherly love. The poem further reveals an existential crisis of the migrant poet when he concludes the poem with two devastating lines:

\section{Life abroad}

Is really a jail

These lines in a way contest a trend of globalization where 'life abroad' may be represented as mobility and multiculturism. For migrant workers like Mukul, life in a foreign land compares to 'jail' and is associated with total confinement and alienation.

Interestingly, the ethos of the book is not wholly consistent. There are two fractures in it, one relating to the nature of the publication and one to the subaltern position of the migrant worker poet.

First, the structure of the book is strange. In the middle of the book, a section titled 'Pieces Together' is inserted, including an introduction to HealthServe by Tan Lai Yong and three poems by student volunteers at the Healthserve community clinic. These poems reflect an attempt to show that the students have a concern for migrant workers. It seems that the HealthServe community clinic wants to display its part in Mukul's 'book formation and life' 
(in Tan's words in the introduction). Such insertions further reveal the power dynamics behind the publication of the book of a migrant worker poet.

Second, Mukul's poetry diverges time and again from his dismay and predicament as a migrant worker in Singapore. In poems such as 'Singapore's Golden Jubilee' and 'Closing Adoration', Mukul adopts an uplifting and laudatory tone, speaking highly of Singapore and its political leader. In 'Singapore's Golden Jubilee', the last stanza says:

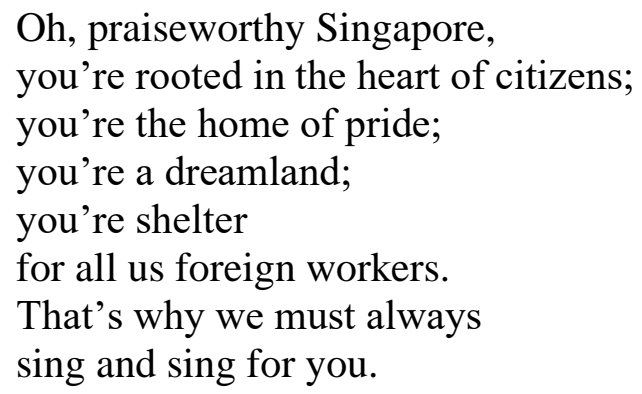

Quite different from other poems, one may find it surprising (if not eerie) to see Mukul embracing Singapore as the 'shelter' of the migrant workers. Moreover, he affirms that 'we must always sing and sing for you' (my emphasis). Obviously, this poem speaks in a very divergent voice and expresses Mukul's admiration of 'praiseworthy' Singapore. Such lines can be also found in the 'closing adoration' where the poet chants for 'Mr. Lee', namely, Lee Kuan Yew: 'You're forever / There is the work of every class of people / In every heartbeat / In my closing adoration oh great leader'. These lines remind us of Md Sharif Uddin's plea concerning the publication of his book: 'No hurt feelings, please!' In a similar vein, one may argue that Mukul shares the concern about exposing his poetry in this way. As Whitehead observed, consciously or unconsciously, the poets 'adopted a politic strategy (that perhaps we all adopt in this place, this climate infected with something vaguely akin to fear) by editing and policing themselves' (Whitehead 2017). Mukul's drastic twist toward self-policing in this poetry collection can be easily seen when he replaces a description of Singapore as a 'jail' where he badly suffers from economical exploitation and emotional alienation with one of Singapore as a 'shelter' which all migrant workers have to praise.

However positive, I still found Singaporean writer Theophilus Kwek's review ${ }^{16}$ of Mukul's book quite disturbing. He thinks that Mukul's poems on Singapore and Bangladesh show 'a sense of cosmopolitan openness, and their permeability to a transcultural traveller like him' (Kwek 2016). That Kwek equates Mukul's migration with a 'cosmopolitan' and 'transcultural' experience appears to be somehow flimsy and perfunctory. The review seems to reflect a quite mechanical neoliberalist portrayal of an 'upper-class' way of migration. In the poem 'Living in Pain', Mukul writes lines such as this one: 'I am a pathless traveller.' Here, we cannot sense any 'cosmopolitan openness,' but only pain.

Compared to Me Migrant, Mukul's second poetry collection Braving Life is more consistent, both in its structure and ethos. It includes 24 poems. Mukul's sensibility and poetic power in language are revealed between his lines. A strong sense of despair and longing for 'home' steer again into his poems, especially when 'home' is embodied as his mother. Interestingly, all the poems are narrated from an 'I' perspective, which by and large unveils Mukul's stringent desire of 'speaking' and claiming his subjectivity through poetry. Also, the 'I' voice poignantly

${ }^{16}$ See: https://singaporereviewofbooks.org/2016/05/26/me-migrant/ 
demands 'ears' to listen. In line with the homesickness of the poems of Me Migrant, some poems in this collection further explore his existential crisis under difficult circumstances. In the poem 'Braving Life' for example, he writes that:

Sometimes I think I shall become a gypsy

Unmasking the disguise of polite society.

Power and position: for them, such birth rights.

Forgetting righteousness and compassion

Like sharpened knives.

Here, 'a gypsy' represents Mukul's wish for divorcing from the pain he suffers and a yearning for freedom and un-belonging to his current being. It also shows his urge of contesting the existing 'polite society'. Meanwhile, in this verse he portrays a 'them' to show readers a vivid contradiction in social relations between the oppressor, those who have 'power and position,' and the oppressed who yearn for freedom, like the 'I'. Moreover, in the following verse, the lines quickly intensify the brutality of such a relation:

Like a newborn, I analyze their cruelty.

Helpless, I lose my words.

Tears no longer run.

Blood searing my veins.

I want to fling everything away. I want a bloodbath.

But Mother comes into my mind.

For the oppressed subject ' $\mathrm{I}$ ' the suppression is overpowering. The reality leaves the 'I' only in a state of being 'helpless'. The verbs change from 'I analyze' to 'I lose', and to a more passive yet aggressive tone: 'I want to fling everything away'. The linguistic transformation in a way portrays the process of alienation for the subaltern workers. Here, the metaphor 'I' like 'a newborn' forms an acute contrast with the 'them' who are like 'sharpened knives', revealing the savageness of the exploitation. A twist appears in the last line, where a 'but' leads to a deeper emotional confession:

I remember a child's voice, Father, a wife's gentle words.

I weep silently in the restroom-eyes exploding hibiscuses,

a headache that kills me. I reach for Panadol.

Like many other migrant poets, Mukul continually seeks comfort and love in his home in Bangladesh; for him it has an aura of sweetness. For example, motherly love is a returning motif in his poems, such as in 'Oh Mother', 'Heart', and 'Child'. While he encounters such an ordeal in Singapore, he harbors in himself the memory of his mother and lover to erase his pain. Yet, even such comfort cannot help. He has to proceed to physical medicine: ' I reach for Panadol'. However short and plain, this poem highlights the predicament of a worker in our society today who can only 'reach for' a pill to remove his pain temporarily.

The word 'pain' keeps recurring in Mukul's poetry. The pains he expresses are both physical and psychological. The amounts of workload torture his body, and he states that the body is always 'exhausted" ${ }^{17}$. There is a poem in this collection titled 'exhaustion' which offers a series of detailed descriptions of the physical sufferings of a worker: 'hemorrhaging heart', 'sickening

\footnotetext{
${ }^{17}$ In his poem 'the migrant's love', he also writes: 'body exhausted by a busy city/ I write a poem for you'.
} 
thirst', and 'tear-sated eyes'. Mukul is sensitive and observant as a poet. Apart from writing about his own emotions and experiences, he catches the life of other marginalized groups in Singapore: the tissue-paper sellers and cleaning ladies. In his poem 'Atman', he writes:

I speak of the tissue-paper seller who sits at the M.R.T station.

I speak of those with cancer

who haven't lost hope.

Those who retain their humanity

do not beg for money-

...

Sometimes, at work, I see

the seventy or eighty-year-old Aunty

searching for cartons in bins.

Eyes wet, I am speechless.

My aged parents rush to mind-a childhood forgotten-

and how they struggled exactly like this

for me.

This poem is particularly interesting in the context of working-class literature from Singapore. In the 1970s, as a Singaporean working-class writer, Chong Han (1945- ) often shed light on the migrant workers who toiled hard in Singapore. For instance, he writers about workers from India in 'Indian Workers ${ }^{18 ،}$ :

In the city, industrial area, paving roads, dredging.........

in the winds and storms, under the hot sun, in the thunderous roar of machines, your traces of laboring are everywhere.

a piece of bedding, a few pieces of old newspaper, under the verandas, in the shabby lanes, home everywhere home nowhere.

Here, we find that working-class writers, such as Chong Han and Mukul, though writing in very different periods and influenced by different ideologies, are still establishing a way of solidarity from below. Both poets are concerned with the life condition of the working-class beyond a national perspective. While they portray a vivid picture of the working people, they both cannot help but questioning; Chong Han asks: 'Why the toiling masses / share the same fate with you?', and Mukul asks: 'I see his reddened face and wonder / What is this life?' We can see these questions as resistant voices challenging social inequality. The answers to these questions, however, display a rather contrasting ethos of two working-class poets. Chong Han concludes his poem with uplifting lines, he promises to the migrant workers:

\footnotetext{
18 The translation is mine.
} 
Yet,

you don't need to be disappointed.

Faith,

ideal......

unite with the waves of struggle of toiling masses.

Together they push the wheel of history leaping forward,

Spring of happiness will certainly come.

Similar to some of his other poems from this period, Chong Han conveys hope and faith in his concluding lines. He is not only hopeful towards a 'spring of happiness', moreover, he believes in the eventual victory of the working-class.

On the contrary, Mukul's poems ends in a very pessimistic and gloomy tone,

People in the narrow lanes:

no one looks, no one hears the sorrow of forgotten folk.

They decorate their lives with colours

of Likes and Dislikes. The gasp in love's ocean.

Those days lie forgotten; time lies unattended-

a tiny signboard, a flute, tissue paper, that wheelchair...

All that they possess.

Mukul sees himself in the 'forgotten folk', identifying with the life of those marginalized Singaporeans. He registers the indifference and brutality of society: 'no one looks, no one hears the sorrow of the forgotten folk'. This powerfully contradicts the mainstream narrative that migrant workers 'cannot speak' as subalterns. It is not the case that workers cannot speak but rather that 'no one' listens to them. Unlike Chong Han, Mukul's poem expresses neither hope nor faith, but despair and loss. It deepens our understanding of how rampant capitalism alienates and confines the workers. Moreover, it vividly displays the transformations of working-class poetry in the context of Singapore. Chong Han wrote working-class poems in the 1970s with a group of leftist Singaporeans. Han explains that 'during this period, the dominant way of literary expression by local leftist writers, commonly known as 'New Realism', was targeted at echoing Mao Zedong's advocacy of literature that serves the proletariats, i.e., workers, peasants and soldiers. In this respect, poetry was combative and regarded as a 'weapon', an essential part of leftist literature' (Han 2004 p.vii). Yet, for today's migrant worker writers, such as Mukul, poetry is neither 'combative' nor a political 'weapon'.

Interestingly, there is also a parallel between Mukul's poetry and Chong Han's later nonpolitical texts: Religious belief recurs in their writings as spiritual comfort and pursuit. Disillusioned by the social transitions and political reality, Chong Han became devoted to Buddhist teachings and preached to people to do good. Mukul, very similar to Sharif, often rests his aspirations and hopes in his belief in Islam. Moreover, religion is a way of rooted bonding between him and other co-workers. In his poem 'Do Not Lose Heart' for example, he encourages his brother Rajeev to hold onto faith in his hard life:

Pray to the Almighty and beg for forgiveness.

Everything waits for you.

In wholeness you will find both your worlds restored.

Your inspiration, your beloved. 
We shall chat our hearts out at the River Drum, consume the night during our happy conversation at Happy Star or Nana Biryani House.

This stanza exhibits Mukul's faith in 'the Almighty'. The speaker in the poem deems that a bright future will be ensured if 'we' do pray and 'beg for forgiveness'. The poet speaks rather upliftingly and is hopeful as to the support by his religious faith. He continues to present imagined happy pictures of the future at his home in Bangladesh, listing specific places such as 'River Drum' and 'Happy Star'. The imagination of a 'happy' future often motivates migrant workers to overcome their hardships and grief.

In the preceding stanza of the poem, Mukul writes: 'Brother Rajeev, don't be afraid / Allah will support you though this trail'. From a Marxist perspective, one could easily argue that Mukul has been governed by his religious belief and under such ideological influence, it is hard for him to articulate the spirit of resistance and rebellion. Ideas such as to overthrow the capitalist system become unlikely. Instead, he dwells on his sufferings and hopes for a 'restored' world. Mukul's case is not unique; almost all aforementioned migrant worker writers from Bangladesh are devoted Muslims. Sharif shares a similar religious attitude. For instance, in his short essay 'Father's Death Anniversary' he muses: 'Like a toddler walking around aimlessly, I shouted at the sky. I said, 'O Allah! Let no one in the world be like me. O Lord, if I have any reward from you then please give it to my parents' (Sharif 2017 p. 143).

While there clearly is a religious aspect and ideological influence in Mukul's writings, I yet hesitate to conclude that their religious ideology makes the migrant workers 'enslaved' and 'degraded' as Marx put it. Rather, when reading migrant worker literature through a religious lens, we gain a picture of their intricate identity formation, and as Barbara Foley suggested, 'a fuller dialectical understanding of the social totality'. I will quote her here at length as she reminds us of the significance of Marxist literary criticism:

The Marxist critic is not a scold, seeking out political shortcomings for exposure and punishment. Rather, the goal of Marxist criticism — and pedagogy — is the development of a fuller dialectical understanding of the social totality giving rise to both doctrines and structures of feeling, whether these clarify or obfuscate the 'real foundation' (Foley 2019 p.159).

\section{Concluding Remark: migrant worker writings and 'catwalk empowerment'}

My main critique regarding the production of Mukul's works concerns its particular mode or cultural form within the capitalistic logic and neoliberal context. The representation of migrant workers and particularly, worker-writers like Md Sharif Uddin and Md Mukul Houssine is worrisomely problematic. The core problem of this kind of 'migrant worker writings' promotion lies in the nature of the whole system: how they are empowered in such a context equally does harm to them. The empowerment of the migrant worker writings in today's Singapore, as I argue, is actually 'catwalk empowerment' as precisely defined by Malin McGlinn: 'that is, empowerment that calls for visual recognition to be meaningful. The project participants, much like models on a fashion catwalk, are shown off in order to attract the gaze of others' (McGlinn 2018 p.214).

Events like migrant worker poetry competitions and the 'Migrant Worker Heroes Festival' are led by the main motivation of 'showcasing' and mass-medializing the migrant worker 
community to exhibit the 'goodness' and 'gratitude' of the Singaporeans. I acknowledge that these events do have an impact on the migrant worker community's visibility, yet, visibility in this context calls for symbolic recognition of the Singaporeans. Again, in line with McGlinn's argument, we can easily find for such migrant workers events that 'the other form of symbolic recognition that is embedded in catwalk empowerment is premised on what Edenborg calls 'the representational mode of visibility.' By this he means a view on visibility 'that is guided by the notion that public visibility is a necessary means for marginalized groups to achieve equality and inclusion"' (McGlinn 2018 p.125). Indeed, in Singapore, the visibility of migrant workers has to be represented in such a showcase format to highlight migrant workers as a marginalized group who need to be revealed and included in the national narrative. The showcase-promotion of migrant worker writings fundamentally functions through 'a sympathetic gaze' producing such representational visibility rather than visibility of the group itself.

In my view, the problematic aspect of exposing the 'visibility' of the migrant workers and their writings in such representations is that this mode again reproduces the systematic structure of power hegemony and social inequality. The 'sympathetic gaze' in the Singaporean context runs through migrant worker writings, from the initiative of organizing and regulating events such as the Migrant Workers Poetry Competition, to the translation and 'transcreation' of Mukul's poetry. However, it is noticeable that the role of sympathy in terms of working-class writings, as Eric Schocket already insightfully examined, is problematic:

But neither does it mean that one can simply assume that sympathy is always or even usually a progressive step towards the amelioration of suffering. Since it is the emotional currency of the very system of relations that produces class suffering, the discourse the affect may, in Ann Cvetkovick's words, 'serve to contain resistance.... Rather than leading to social change, the expression of feeling can become an end in itself or an individual solution to systematic problems (Schocket 2006 p. 6).

When the migrant worker writers are 'produced' and 'empowered' through such a sympathetic gaze, paradoxically, at the same time, their works are somehow made suitable for onedimensional consumption. The sympathy shown towards the migrant workers in such a way easily lends itself as a means of expressing one's feeling, one's goodness, or one's gratitude. It is very obvious that in Mukul's case people sympathized with him for being a migrant worker poet with talent and they helped him. But the very fact that he was made relatively famous as a writer also led to his eventual inability to stay in Singapore and to accusations of wanting to be a poet only for fame and fortune.

\section{Author Bio}

Luka Lei Zhang is a $\mathrm{PhD}$ candidate in English at Nanyang Technological University, Singapore. She received her Master's Degree from the University of Macau. She works on the $\mathrm{PhD}$ project 'Modes of Productions of Working-class Literature from Asia' and is a translator of working-class poetry.

\section{Bibliography}

Bal, C. (2017). Myth and facts: migrant workers in Singapore. In Loh \& Tjin (Eds.). Living with myths in Singapore.(pp.201-219). Ethos Books. 
Bassnett, S., \& Trivedi, H. (Eds.). (1999). Post-colonial translation: theory and practice. Routledge.

Cheah, P. (2016). What is a world? : on Postcolonial Literature as World Literature. Duke University Press.

Chong, H. 赤道鼓声.(1972). Drums on the Equator. 群山出版社.

Foley, Barbara. (2019). Marxist Literary Criticism Today. Pluto Press.

Goh, Tong., \& Yeh, Ray. (Producers). (2019 August 15). 'He got too famous': A Construction Worker Turned Poet Pays the Price' [Video]. CAN Insider. YouTube. https://www.youtube.com/watch?v=pTrW5y6dtvA

Han, T. (2004). A Study of Chinese Leftist Poetry in Singapore 1965-1975. 《新加坡左派 诗歌研究》 [ Master's Thesis, National University of Singapore]. ProQuest Dissertations and Theses Global.

Hossine, M., Md. (2016). Me Migrant. Ethos Books.

Hossine, M., Md. (2017). Braving Life. HealthServe.

Kewk, T. (2016 May 26). Book Review on Me Migrant. https://singaporereviewofbooks.org/2016/05/26/me-migrant/

Marx, K. (2010). A Contribution to the Critique of Political Economy. In: Sitton J.F. (eds) Marx Today. Palgrave Macmillan. 91-94.

McGlinn, Glinn. (2018). Translating Neoliberalism: The European Social Fund and the Governing of Unemployment and Social Exclusion in Malmö, Sweden. [Doctoral dissertation, Malmö University]. ProQuest Dissertations and Theses Global.

Schocket, E. (2006). Vanishing Moments: Class and American Literature. The University of Michigan Press.

Sharif, Md. U. (2017). Stranger to Myself. Diary of a Bangladeshi in Singapore. Landmark Books.

Shipon, F.O. (2019). Migrant Life: Stories of Reverist. Babui Prokashoni.

Teo, Y. (2019). This is What Inequality Looks Like, Essays by Teo You Yenn. Ethos Books.

Whitehead, R. A. (2017 June 13). Migrant Tales. Singapore Unbound. https://singaporeunbound.org/blog/2017/6/10/18j7o5n9rdw6qbci6i0kkkpk0inf8r

Zhang, L.L. (2020). From Red Scare to Capitalist Showcase: Working-Class Literature from Singapore. In J. Lennon and M. Nilsson (eds.) Working-Class Literature(s): Historical and International Perspectives. Volume 2. Stockholm University Press. 139-164. 